\title{
Zinc concentrations in the cerebrospinal fluid of normal adults and patients with neurological diseases
}

\author{
R PALM, ${ }^{*}$ G HALLMANS $\dagger$ \\ From the Biophysical Laboratory and the Departments of Neurology* and Pathology, $\dagger$ University of Umea, \\ Umed, Sweden
}

SUMMARY Zinc concentrations in CSF were determined with flame atomic absorption spectrophotometry in patients assumed to have a normal CSF. No sex difference was found. There was a correlation between zinc, protein and albumin concentrations in CSF. In patients with increased protein levels in CSF or subarachnoid haemorrhage increased zinc concentrations were found.

Zinc $(\mathrm{Zn})$ is a necessary component of many metalloenzymes, ${ }^{1}$ some of which are known to be of importance for the function of CNS for example, RNA and DNA polymerase and carbonic anhydrase. Zinc deficiency in rats may lead to malformations of the CNS. ${ }^{2}$ Zinc deficiency has been suggested as an explanation for the CNS symptoms in liver cirrhosis, foetal alcohol syndrome, malabsorption and acrodermatitis enteropathica. ${ }^{3}$ Low serum or plasma concentrations of $\mathrm{Zn}$ have been found in multiple sclerosis ${ }^{45}$ and in chronic alcoholics with liver disease. ${ }^{6}$ High concentrations have been found in multiple sclerosis ${ }^{7}$ and Pick's disease. ${ }^{8}$ There are few reports of $\mathrm{Zn}$ concentrations in normal CSF and in CSF from patients with neurological diseases. ${ }^{9}$ Low CSF $\mathrm{Zn}$ concentrations have been found in patients with alcohol withdrawal seizures ${ }^{10}$ and increased concentrations have been reported in patients on oestrogen therapy. ${ }^{11}$ Increased CSF $\mathrm{Zn}$ levels also were noted in patients with increased CSF protein concentrations. ${ }^{12}$ Other authors ${ }^{15-16}$ have not found any relation between CSF $\mathrm{Zn}$ and CSF protein concentrations.

In a previous study Palm et al, ${ }^{9}$ described a method for the determination of CSF $\mathrm{Zn}$ by flame atomic absorption spectrophotometry (AAS) utilising a pulse nebuliser technique. Lower CSF Zn levels were found compared with earlier reports. The aim of the present study was to investigate the CSF $\mathrm{Zn}$ concentrations in patients assumed to have a normal CSF, and in patients with increased CSF protein concentrations, brain tumours, zinc deficiency, subarachnoid haemorrhage and in patients

\footnotetext{
Address for reprint requests: Dr R Palm, Dept of Neurology, University Hospital, S-901 85 Umeå, Sweden.

Received 5 February 1982. Accepted 9 April 1982
}

on oestrogen and corticosteroid treatment. These drugs are known to induce low serum $\mathrm{Zn}$ concentration.

\section{Patients and methods}

\section{Patients Controls}

The controls were 18 healthy volunteers, nine males, mean age $28 \pm 4(\mathrm{SD})$ years, and nine females, mean age $30 \pm 4^{\circ}$ years and 34 patients assumed to have a normal CSF. Of the patients 14 were males, mean age $38 \pm 11$ years, and 20 females, mean age $42 \pm 11$ years. They had attended the neurological clinic because of headache, dizziness, vasovagal syncope, neuralgic pain and other pain syndromes or psychoneurosis; a lumbar puncture was performed for diagnostic reasons. The neurological examination did not reveal any objective signs of a lesion in the CNS. They had no signs of acute or chronic infection, liver disease or alcoholism and were not being treated with corticosteroids, ACTH, oral contraceptives or chelating drugs. None of the women was pregnant. The ESR was below $25 \mathrm{~mm} / \mathrm{h}$ and the $\mathrm{Hb}$ was more than $115 \mathrm{~g} / \mathrm{l}$ in all cases. The CSF was macroscopically clear and uncoloured, had a leucocyte count of less than $5 / \mu l$ and the CSF protein was less than $500 \mathrm{mg} /$. These controls were used as age- and sexmatched controls to the other patients.

Patients with increased CSF protein concentrations $(\mathrm{n}=11$; table 3) Six of the patients were males, five were females. All had a CSF protein level over $750 \mathrm{mg} /$. In this group there were patients with untreated $(n=5)$ or corticosteroid treated $(n=2)$ Guillain-Barré syndrome, patients with myelopathy of unknown cause $(n=2)$, one patient with cervical disc herniation and a partial spinal block and one patient with increased CSF protein concentration two years after an intracerebral bleed.

Patients with brain tumours ( $\mathrm{n}=12$; table 3 ) Ten patients, five males and five females, suffered from malignant brain tumours. Eight had malignant gliomas and two had cerebral metastasis. Two patients, one of each sex, had meningiomas. 
Patients with zinc deficiency ( $\mathrm{n}=5$; table 3 ) Four patients with chronic alcoholism, three males and one female, and a female with malabsorption after a jejuno-ileal shunt were included in this group. All had a serum $\mathrm{Zn}$ level below $10 \cdot 0$ $\mu \mathrm{mol} / \mathrm{h}$.

Patients treated with oestrogens and corticosteroids $(\mathrm{n}=12$; table 3) Six females were on oral contraceptives (oestrogen + progestogen). Four had had symptoms of transitory ischaemic attacks, one had lumbago and one suffered from paresthaesies. Two females were on oestrogens, one of them showed torticollis, while the other had multiple sclerosis. Four patients, three males and one female, were on corticosteroid therapy with prednisolone because of polyneuropathy $(n=2)$ or optic neuritis $(n=2)$.

Patients with subarachnoid haemorrhage $(n=6)$ Five patients were males and one a female. The mean age of the group was $57 \pm 11$ years. The bleeding source in all cases was a ruptured arterial aneurysm. Four of the patients were seriously ill and required parenteral nutrition. Samples were obtained within three days of the subarachnoid haemorrhage from five patients. The CSF sample from the sixth patient was obtained on the 18 th day after the initial subarachnoid haemorrhage when a second bleed occurred.

\section{Methods}

The CSF samples were taken after overnight fast at 08.00-09.00 except in the patients with subarachnoid haemorrhage. The lumbar puncture was performed in the lateral recumbent position after $10-30$ min rest. The skin was anaesthesized with one $\mathrm{ml}$ of Xylocain $10 \mathrm{mg} / \mathrm{ml}$ (Astra, Sweden) and the lumbar puncture performed with a sterile disposable hypodermic needle $0.9 \times 90 \mathrm{~mm}$ (Mediplast, Sweden). The first two ml were taken for cell count. CSF samples for $\mathrm{Zn}$, protein and albumin analysis were taken from the 10 th to the 17 th $\mathrm{ml}$ in the healthy volunteers and in the patients from the fifth to the 20th ml. CSF was allowed to drop directly into acid washed plastic tubes, which were immediately sealed with Parafilm (American Can Company, USA) and frozen at $-20^{\circ} \mathrm{C}$ until analysed. The CSF samples were not centrifuged or transferred to other tubes. CSF samples with signs of traumatic spinal tap were rejected.

CSF samples from the patients with subarachnoid haemorrhage were taken through a catheter in the lateral ventricle. The samples were aspirated with a zinc free syringe. The first two $\mathrm{ml}$ were rejected and the following eight $\mathrm{ml}$ transferred to an acid washed glass tube and centrifuged at $5000 \mathrm{rpm}$ for 15 minutes. The supernatant was then transferred to acid washed plastic tubes by zinc free Pasteur pipettes and frozen at $-20^{\circ} \mathrm{C}$.

Blood samples were taken immediately after the lumbar puncture from an antecubital vein after minimal stasis. The blood was collected in acid washed glass tubes, allowed to clot for two hours, centrifuged at $5000 \mathrm{rpm}$ for 10 minutes and the serum transferred to acid washed plastic tubes with Pasteur pipettes. The tubes were sealed with Parafilm and frozen at $-20^{\circ} \mathrm{C}$. Serum samples were not obtained from the patients with subarachnoid haemorrhage.

The CSF $\mathrm{Zn}$ analysis was performed with flame AAS. ${ }^{16}$ Standards in $0.150 \mathrm{~mol} / \mathrm{NaCl}$ were used. The samples for serum $\mathrm{Zn}$ analysis were diluted eleven times with $0.1 \mathrm{~mol} / \mathrm{A}$ $\mathrm{HCl}$ and the $\mathrm{Zn}$ concentrations determined with flame
AAS. ${ }^{16}$ The CSF protein concentrations were determined according to Lowry et al ${ }^{17}$ with tyrosine as the standard. The concentrations of CSF albumin and serum albumin were determined by electroimmuno-assay according to Laurell $^{18}$ with human albumin (Kabi, Sweden) as the standard.

\section{Statistics}

The differences between group means in the controls for different variables were tested using Student's $t$ test. The test was modified if the variances were significantly different $(p<0.01 ;$ F-test $)$. Product moment correlation coefficients $(r)$ were calculated for selected variables and tested using Student's $t$ test. In the patients with neurological diseases Wilcoxon matched-pairs signed-ranks test was used and Spearman correlation coefficients determined. $p$ $<0.05^{\mathrm{x}}, \mathrm{p}<0.01^{\mathrm{xx}}$, and $\mathrm{p}<0.001^{\mathrm{xxx}}$ were chosen as levels of statistical significance.

\section{Results}

\section{CONTROLS}

The frequency distribution of the CSF $\mathrm{Zn}$ concentrations is seen in fig 1 . There were no sex differences in CSF $\mathrm{Zn}, \mathrm{CSF}$ protein, CSF albumin concentrations or in the CSF/serum albumin ratio (table 1). Higher serum $\mathrm{Zn}$ levels were found in the males. When CSF $\mathrm{Zn}$ was correlated with different parameters, positive correlations were found between CSF $\mathrm{Zn}$ and CSF protein, CSF $\mathrm{Zn}$ and CSF albumin and $C S F ~ Z n$ and CSF/serum albumin ratio (table 2 ). The best correlation was found between CSF $\mathrm{Zn}$ and CSF albumin (fig 2). No correlation was found between CSF $Z_{n}$ and serum $Z_{n}$. Serum $Z_{n}$ was negatively correlated to age for males + females $(\mathrm{r}=0.33, \mathrm{p}=0.021)$.

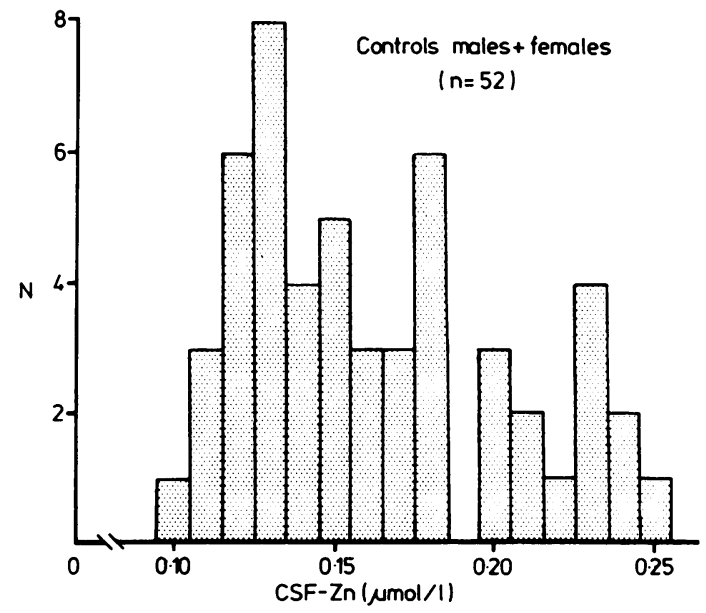

Fig 1 The frequency distribution for the CSF $\mathrm{Zn}$ concentrations in the controls. 
Table 1 CSF Zn, CSF protein, CSF albumin and serum $Z n$ concentrations and CSF/serum albumin ratio in controls. The results are given as the mean $\pm S D$. There is a significant sex difference only for the serum $Z n$ concentrations $(p=0.024)$.

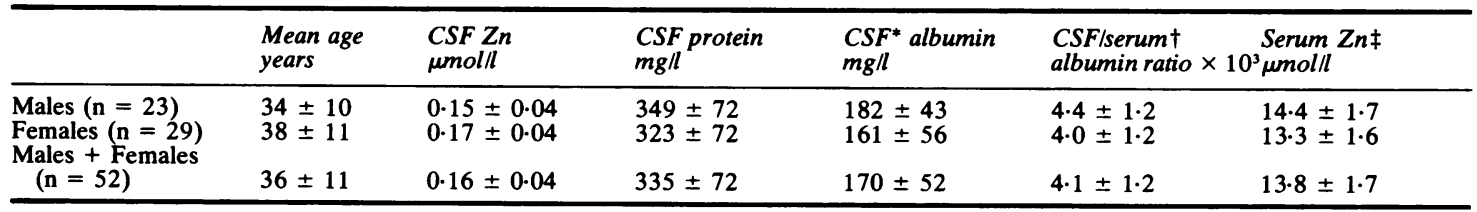

${ }^{*} \mathrm{n}=47$ (19 males, 28 females)

tn $=44$ (18 males, 26 females)

$\ddagger \mathrm{n}=48$ (22 males, 26 females)

Table 2 Correlation coefficients between CSF $Z n$ and CSF protein, CSF albumin, CSF/serum albumin ratio, and serum $\mathrm{Zn}$ in the controls.

\begin{tabular}{lllll}
\hline & $\begin{array}{l}\text { CSF protein- } \\
\text { CSF Zn }\end{array}$ & $\begin{array}{l}\text { CSF albumin- } \\
\text { CSF Zn }\end{array}$ & $\begin{array}{l}\text { CSF/serum albumin- } \\
\text { CSF Zn }\end{array}$ & $\begin{array}{l}\text { Serum }(s) Z n-~ \\
\text { CSF Zn }\end{array}$ \\
\hline Males $(\mathrm{n}=23)$ & $\mathrm{r}=0.41$ & $\mathrm{r}=0.65$ & $\mathrm{r}=0.74$ & $\mathrm{r}=0.20$ \\
& $\mathrm{p}=0.049$ & $\mathrm{p}=0.003$ & $\mathrm{p}=0.001$ & $\mathrm{p}=0.377$ \\
Females $(\mathrm{n}=29)$ & $\mathrm{r}=0.38$ & $\mathrm{r}=0.44$ & $\mathrm{r}=0.23$ & -0.30 \\
Males + Females & $\mathrm{p}=0.038$ & $\mathrm{p}=0.018$ & $\mathrm{p}=0.257$ & $\mathrm{p}=0.137$ \\
$(\mathrm{n}=52)$ & $\mathrm{p}=0.35$ & $\mathrm{r}=0.47$ & $\mathrm{r}=0.40$ & -0.12 \\
\hline
\end{tabular}

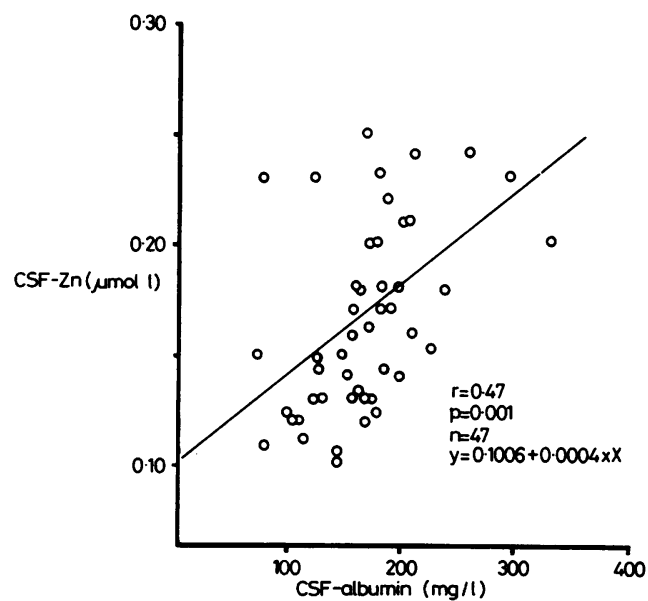

Fig 2 CSF albumin and CSF Zn concentrations in 47 controls.

\section{PATIENTS WITH NEUROLOGICAL DISEASES}

Increased CSF $\mathrm{Zn}$ levels were noted in patients with Guillain-Barré syndrome as well as in those with other causes of blood-brain-barrier damage (table 3 ). The two patients with Guillain-Barre syndrome on corticosteroid therapy did not differ from the other such patients in CSF $\mathrm{Zn}$ or CSF protein parameters.

Patients with malignant brain tumours had increased CSF Zn concentrations, especially those with increased CSF protein levels (table 3; fig 3). Four had CSF protein concentrations over $0.750 \mathrm{~g} / 1$ and their CSF $\mathrm{Zn}$ was $0.42 \pm 0.12 \mu \mathrm{mol} / \mathrm{l}$. In the remaining six patients the CSF $\mathrm{Zn}$ level was $0 \cdot 24 \pm$ $0 \cdot 16$. The two patients with meningiomas had CSF $\mathrm{Zn}$ levels $(0.14 \pm 0.02 \mu \mathrm{mol} / \mathrm{l})$ that did not differ from the controls.

In the zinc deficient patients there was no difference in CSF $\mathrm{Zn}$ or protein parameters compared with the controls (table 3 ). The serum $\mathrm{Zn}$ levels were low in the patients.

Neither oral contraceptives, oestrogen therapy nor corticosteroid therapy altered CSF $\mathrm{Zn}$ or CSF protein concentrations (table 3 ).

The patients with subarachnoid haemorrhage had considerably increased CSF $\mathrm{Zn}$ levels (1.68 \pm 1.22 $\mu \mathrm{mol} / \mathrm{l})($ fig 3$)$. Their CSF protein concentration was also increased $(2133 \pm 1052 \mathrm{mg} / \mathrm{l})$.

In the patients with increased CSF protein levels there was no correlation between CSF $\mathrm{Zn}$ and the protein parameters in CSF.

\section{Discussion}

Considerable lower "normal" CSF Zn concentrations have been found with the present analytical method compared to those found in most other laboratories (for reference see ref. 9). Only Kjellin ${ }^{19}$ using neutron activation analysis reported CSF $Z_{\mathbf{n}}$ concentrations almost in the same range as in the present study. Contamination problems, ${ }^{20}$ nonatomic absorption, ${ }^{21}$ and different analytical methods may explain the scattered high levels 
Table 3 CSF Zn, CSF protein, CSF albumin, serum Zn concentrations and CSF/serum albumin ratio in some neurological diseases. The results are given as the mean $\pm S D$ and are compared with the controls (Wilcoxon matched-pairs signed-ranks test).

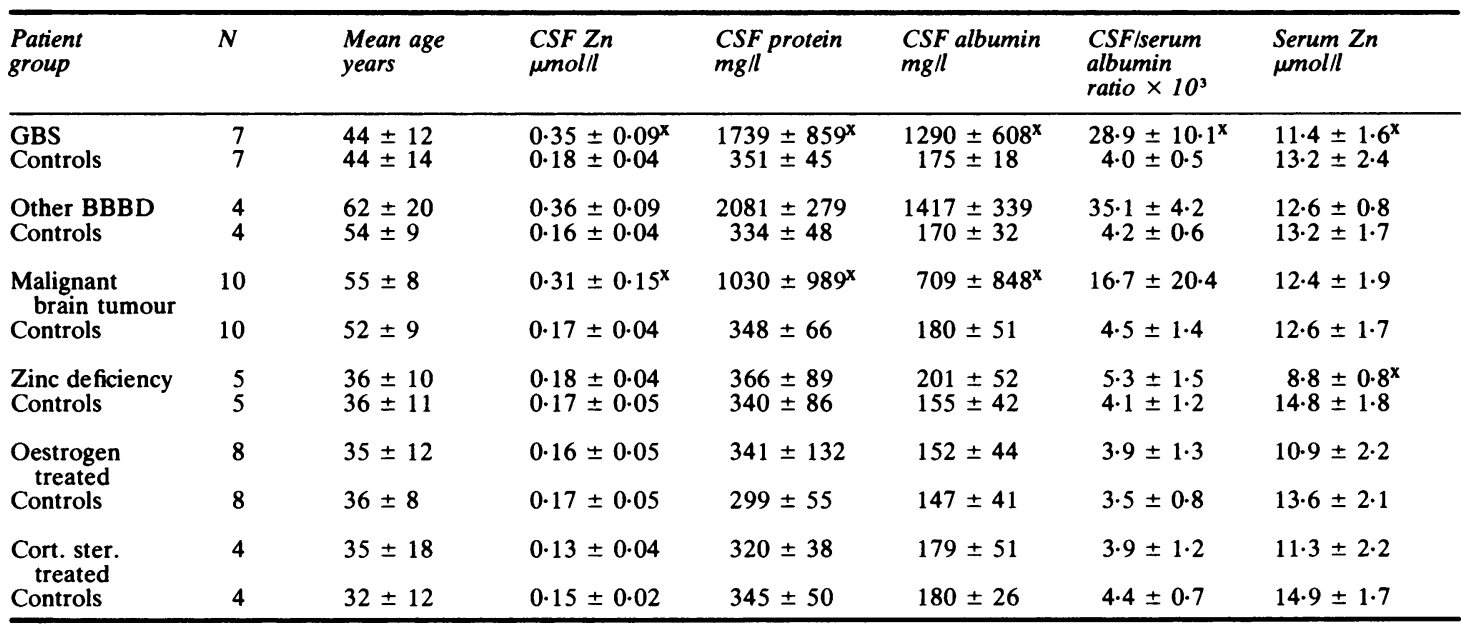

GBS = Guillain-Barré syndrome, BBBD = Blood brain barrier damage.

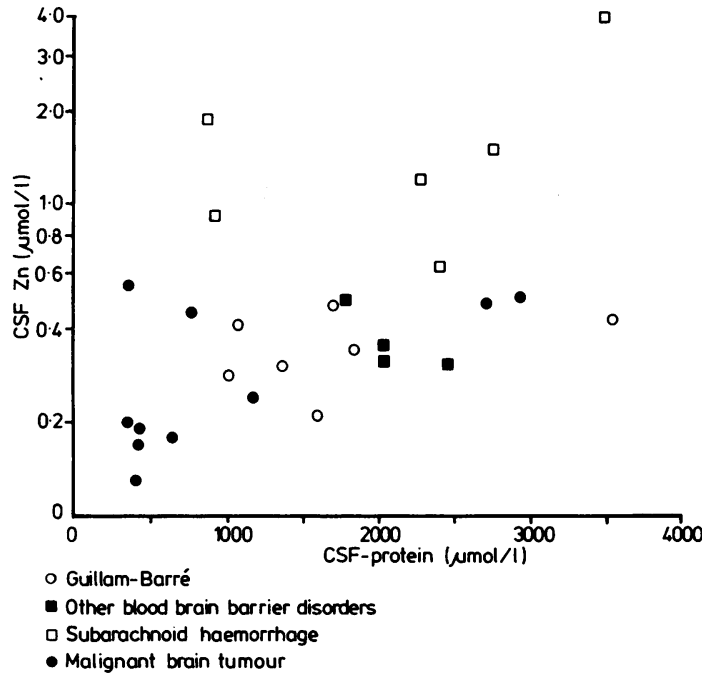

Fig 3 CSF Zn and CSF protein concentrations in patients with Guillain-Barré syndrome $(n=7)$, malignant brain tumours $(n=10)$, subarachnoid haemorrhage $(n=6)$, and patients with other causes for blood-brain-barrier damage $(n=4)$. The scale on the $y$-axis is a log scale.

obtained by others. In the present study the normal CSF $\mathrm{Zn}$ levels showed small variations but the sex difference found in the serum $\mathrm{Zn}$ levels was not noted in CSF $\mathrm{Zn}$. The CSF protein, CSF albumin and serum $\mathrm{Zn}$ concentrations and the CSF/serum albumin ratio in the controls were within the normal range. ${ }^{22-25}$ The CSF/serum albumin ratio is consi- dered to be a good test of blood brain barrier function. ${ }^{22} \mathrm{~A}$ sex difference was not found in the protein parameters in CSF as has been reported by some authors. ${ }^{23}$ Increased protein parameters in CSF with increasing age has been reported. ${ }^{22}{ }^{26} \mathrm{In}$ the present study no conclusions could be drawn concerning the age dependency of CSF protein parameters or CSF Zn.

The positive correlation between CSF $\mathrm{Zn}$ and protein parameters in the normal patients has been reported previously for healthy volunteers, ${ }^{9}$ where the best correlation, however, was found between CSF $\mathrm{Zn}$ and CSF protein. It is not known if the $\mathrm{Zn}$ in CSF is bound to proteins and amino acids. In serum $\mathrm{Zn}$ is bound mainly to albumin (about $80 \%$ ) and to $\alpha_{2}$-macroglobulin $(20 \%) .{ }^{27}$ A small part is also bound to amino acids such as histidine and cysteine ${ }^{28} \mathrm{CSF}$ albumin derives from serum albumin ${ }^{29}$ and the concentration of $\alpha_{2}$-macroglobulin in CSF is low. ${ }^{30}$ The serum to CSF ratio for albumin is about 200:1, ${ }^{22}$ for histidine $6: 1^{31}$ and for $\mathrm{Zn} 90: 1$ (present study). The good correlation between CSF $\mathrm{Zn}$ and CSF albumin in the controls indicates that most of the $\mathrm{Zn}$ in CSF is bound to albumin. The proportionally high CSF levels of amino acids and low level of $\alpha_{2}$-macroglobulin suggests that relatively more $\mathrm{Zn}$ is bound to amino acids in CSF than in serum.

The increased CSF $\mathrm{Zn}$ concentrations in patients with high CSF protein levels reflects blood brain barrier damage with leakage of $\mathrm{Zn}$-binding proteins from serum to CSF. These increased CSF $\mathrm{Zn}$ levels are in accordance with Kjellin, ${ }^{12}$ but not with other reports. ${ }^{13-15}$ 
In the patients with brain tumours high CSF Zn levels were found in those with increased CSF protein concentrations, which probably is a result of a blood brain barrier damage, but also in some patients with normal CSF protein levels. An explanation to the latter finding may be that small bleedings occur in some of the malignant tumours. Erythrocytes have a high content of $\mathrm{Zn}^{32}$ and $\mathrm{Zn}$ from haemolysed erythrocytes may reach the CNS to increase the CSF $\mathrm{Zn}$ concentrations. In spite of the correlations between CSF $\mathrm{Zn}$ and protein parameters in CSF in the controls, no correlation was found in the patients with increased CSF protein concentrations, perhaps because there were few patients.

Bleeding causes the high CSF $\mathrm{Zn}$ levels in patients with subarachnoid haemorrhage. The CSF samples in such patients were obtained from the lateral ventricle. This can not explain, however, the great differences in CSF $\mathrm{Zn}$ concentrations compared to normal CSF. Ventricular CSF has a lower protein concentration than lumbar $\mathrm{CSF}^{33}$ and because of the correlation between $\mathrm{Zn}$ and proteins in CSF a low CSF $\mathrm{Zn}$ concentration should be found normally in ventricular CSF. The high CSF $\mathrm{Zn}$ levels found in the patients with subarachnoid haemorrhage are in contrast to the reports by Bogden et al ${ }^{14}$ who found normal CSF $\mathrm{Zn}$ levels in nine patients with subarachnoid haemorrhage.

In the healthy volunteers ${ }^{9}$ a positive correlation was found between CSF $\mathrm{Zn}$ and serum $\mathrm{Zn}$ concentrations in the males. In the normal patients, in zinc deficient patients or in those with drug induced low serum $\mathrm{Zn}$ concentrations this correlation was not found. One reason to the divergence may be that the CSF sampling was more standardised in the volunteers. In oral contraceptives, the oestrogen component reduces the serum $\mathrm{Zn}$ levels. ${ }^{34}$ Females on oral contraceptives and oestrogens consequently were grouped together. Increased CSF Zn concentrations during oestrogen therapy as reported by Bogden and Troiano ${ }^{10}$ could not be verified in the present study. Corticosteroids also decrease the serum $\mathrm{Zn}$ concentrations. ${ }^{35}$ In the present study there were few patients on corticosteroid therapy and the serum concentrations in this group did not differ significantly from that in the control group. The lack of correlation between CSF $\mathrm{Zn}$ and serum $\mathrm{Zn}$ levels was also reported earlier. ${ }^{13} 14$

In conclusion, CSF $\mathrm{Zn}$ concentrations normally are correlated with the CSF protein and CSF albumin concentrations, as well as to the CSF/serum albumin ratio, but not to the serum $\mathrm{Zn}$ levels. In patients with the blood brain barrier damage and subarachnoid haemorrhage the CSF Zn concentrations increase. Increased concentrations were also found in some patients with malignant brain tumours with normal CSF protein levels. The importance of CSF $\mathrm{Zn}$ determinations in other neurological diseases should be evaluated.

The skilfull technical assistance of Inger Sjöström and Ann-Marie Åhrén is gratefully acknowledged. This work was supported by grants from Amanda Wilhelmina and Per Algot Mångberg's Foundation for Medical Research, Karl Oskar Hansson's Foundation, Anders Otto Swärd's Foundation, The MS Foundation and The Faculty of Medicine, Umeå University.

\section{References}

' Riordan JF. Biochemistry of zinc. Med Clin North Am 1976;60:661-74.

${ }^{2}$ Hurley LS, Sharader RE. Congenital malformations of the nervous system in zinc-deficient rats. Int $R e v$ Neurobiol Suppl 1972;1:7-51.

${ }^{3}$ Prasad AS. Clinical, biochemical, and pharmacological role of zinc. Ann Rev Pharmacol Toxicol 1979;20:393-426.

${ }^{4}$ Wong Jr EK, Enomoto H, Leopold IH, et al. Plasma zinc levels in multiple sclerosis. Metab Pediatr Ophthalmol 1980;4:3-8.

${ }^{5}$ Palm R, Hallmans G. Zinc and copper in multiple sclerosis. J Neurol Neurosurg Psychiatry. 1982;45:691-698

- Vallee BL, Wacker WEC, Bartholomay AF, Hoch FL. Zinc metabolism in hepatic dysfunction. $N$ Engl $J$ Med 1957;257:1055-65.

${ }^{7}$ Dore-Duffy P, Catalanatto F, Ostrom M, Donaldson JO. Zinc in multiple sclerosis. Ann Neurol 1981;10:97.

${ }^{8}$ Constantinidis J, Richard J, Tissot R. Maladie de Pick et métabolisme du zinc. Rev Neurol (Paris) 1977;133:685-96.

${ }^{9}$ Palm R, Sjöström R, Hallmans G. Determination of zinc in cerebrospinal fluid. In press. Clin Chem.

${ }^{10}$ Bogden JD, Troiano RA. Plasma calcium, copper, magnesium and zinc concentrations in patients with alcohol withdrawal syndrome. Clin Chem 1978;24:1553-6.

${ }^{11}$ McCall JT, Goldstein NP, Smith LH. Implications of trace metals in human diseases. Fed Proc 1971;30:1011-5.

${ }^{12} \mathrm{Kjellin}$ KG. Trace elements in the cerebrospinal fluid. In: Nuclear activation techniques in the life sciences. Vienna, International atomic energy agency, 1967:517-32.

${ }^{13}$ Woodbury J, Lyons K, Carretta R, Hahn A, Sullivan JF. Cerebrospinal fluid and serum levels of magnesium, zinc and calcium in man. Neurology (Minneap) 1968;18:700-5.

${ }^{14}$ Bogden JD, Troiano RA, Joselow MA. Copper, zinc, magnesium, and calcium in plasma and cerebrospinal fluid of patients with neurological diseases. Clin Chem 1977;23:485-9. 
${ }^{15}$ Kotlarek F, Berg W. Die Spurenelemente Kupfer und Zinc im Liquor von Kindern mit neurologischen Erkrankungen. Mscr Kinderheilkd 1978;126:719-21.

${ }^{16}$ Hallmans G. Absorption of topically applied zinc and changes in zinc metabolism during wound healing. An experimental and clinical investigation. Acta Derm Venereol 1978;58, suppl 80:9.

${ }^{17}$ Lowry OH, Rosebrough NJ, Farr AL, Randall RJ. Protein measurement with the folin phenol reagent. $J$ Biol Chem 1951;193:265-75.

${ }^{18}$ Laurell C-B. Electroimmuno Assay. Scand J CLin Lab Invest 1972;29, suppl 124:21-37.

${ }^{19}$ Kjellin KG. Aktiveringsanalys av spårmetaller. Nord Med 1965;74:804-5.

${ }^{20}$ Reimold EW, Besch DJ. Detection and elimination of contaminations interfering with the determination of zinc in plasma. Clin Chem 1978;24:675-80.

${ }^{21} \mathrm{Kahn}$ HL, Manning DC. Background correction in atomic absorption spectroscopy. Amer Lab 1972;4:51-6.

22 Tibbling G, Link H, Öhman S. Principles of albumin and IgG analyses in neurological disorders. I. Establishment of reference values. Scand J Clin Lab Invest 1977;37:385-90.

${ }^{23}$ Breebaart K, Becker H, Jongebloed FA. Investigation of reference values of components of cerebrospinal fluid. $J$ Clin Chem Clin Biochem 1978;16:561-5.

${ }^{24}$ Kiilerich S, Christensen MS, Naestoft J, Christiansen C. Determination of zinc in serum and urine by atomic absorption spectrophotometry; relationship between serum levels of zinc and proteins in 104 normal subjects. Clin Chim Acta 1980;105:231-9.

${ }_{25}$ Versieck J, Cornelis R. Normal levels of trace elements in human blood plasma or serum. Anal Chim Acta 1980;116:217-54.

${ }^{26}$ Ganrot K, Laurell C-B. Measurement of IgG and albumin content of cerebrospinal fluid, and its interpretation. Clin Chem 1974;20:571-3.

${ }^{27}$ Giroux EL, Durieux M, Schechter PJ. A study of zinc distribution in human serum. Bioinorg Chem 1976;5:211-8.

${ }^{28}$ Giroux EL, Henkin RI. Competition for zinc among serum albumin and amino acids. Biochim Biophys Acta 1972;273:64-72.

${ }^{29}$ Cutler RWP, Deuel RK, Barlow CF. Albumin exchange between plasma and cerebrospinal fluid. Arch Neurol 1967;17:261-70.

${ }^{30}$ Schliep G, Felgenhauer K. Serum-CSF protein gradients, the blood-CSF barrier and the local immune response. J Neurol 1978;218:77-96.

${ }^{31}$ McGale EHF, Pye IF, Stonier C, Hutchinson EC, Aber GM. Studies of the interrelationship between cerebrospinal fluid and plasma amino acid concentrations in normal individuals. J Neurochem 1977;29:291-8.

${ }^{32}$ Stevens MD, MacKenzie WF, Anand VA. A simplified method for determination of zinc in whole blood, plasma, and erythrocytes by atomic absorption spectrophotometry. Biochem Med 1977;18:158-63.

${ }^{33}$ Weisner B, Bernhardt W. Protein fractions of lumbar, cisternal, and ventricular cerebrospinal fluid. $J$ Neurol Sci 1978;37:205-14.

${ }^{34}$ Halsted JA, Hackley BM, Smith JC Jr. Plasma-zinc and copper in pregnancy and after oral contraceptives. Lancet I 1968:278-9.

${ }^{35}$ Henkin RI, Meret S, Jacobs JB. Steroid-dependent changes in copper and zinc metabolism. $J$ Clin Invest 1969;48:38a. 